\title{
Alceste de eurípide pelo prisma da Poética de Aristóteles
}

Luciene Lages Silva

UFMG

\begin{abstract}
RESUMO
Muitas controvérsias existem acerca do gênero trágico de Alceste. E o grande desafio nesta peça é redescubri-la nas premissas aristotélicas que definem uma tragédia. Eurípides despertará a compaixão (éleos) e o temor (phóbos), levando o público à catarse (khatársis), mesmo que para isso seja preciso introduzir inovações em cena e modificações no mito.
\end{abstract}

PALAVRAS-CHAVE

éleos, phóbos, khatársis

Agir como se a morte não existisse, ou agir pensando na morte a cada instante é, talvez, a mesma coisa.

Nikos Kazantzakis

No capítulo seis da Poética," Aristóteles define a tragédia "como a initação de uma ação completa, de caráter elevado que suscita o temor e a compaixão, e que tem por efeito a purificação destas emoções". Essa definição apresenta três palavras chaves: phóbos, éleos, kathársis. Vale a pena refletirmos um pouco sobre o temor, a compaixão e a catarse provocados por Alceste.

O tema central de Alceste está presente em várias culturas e em todas as épocas: o sacrifício por amor através da morte. Segundo Lesky, ${ }^{2}$ o mito original tinha como momento sacrificial as bodas de Admeto e Alceste. Eurípides, então, introduz uma modificação relevante, quando transfere este momento para alguns anos mais tarde.

Isso nos permite pensar que o sacrifício pelo homem amado seria até natural, quando se tratasse de uma noiva apaixonada que dá uma prova incondicional do seu amor. Contudo, ao permitir que a personagem vivesse alguns anos mais e se tornasse mãe, Eurípides nos faz crer que Alceste, ao sacrificar-se por Admeto, fê-lo principalmente em prol das crianças, que poderiam ter o futuro totalmente comprometido pelo fato de o pai, um rei, não estar mais entre elas, e, ainda, possuírem como mãe uma estrangeira.

No diálogo de Alceste e Admeto, a jovem esposa declara:

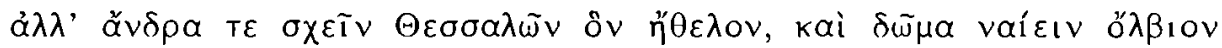

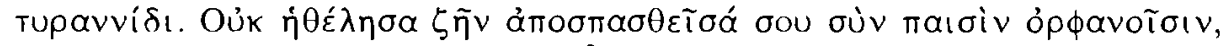

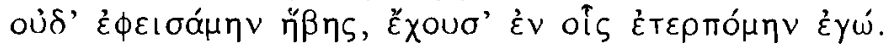

\footnotetext{
${ }^{1}$ Aristóteles. Poética, c.6, 1449B, 24-6.

${ }^{2}$ LESKY. A tragédia grega, p.165-6.
} 
Entre os Tessálios poderia escolher esposo que me agradasse e habitar, na realeza, uma próspera casa. Não quis, porém, viver separada de ti com filhos órfãos, nem te regateei o sacrifício da minha juventude e dos seus dons, que causavam a minha alegria. $^{3}$

Entretanto, o fato de o poeta acrescentar um elemento novo não diminui em nada a verossimilhança do mito. Neste caso, até contribui para facilitar a construção da compaixão. Aristóteles alerta-nos:

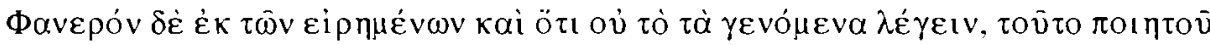

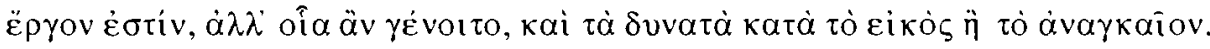

E é evidente também, a partir das coisas ditas, que o dizer as coisas que aconteceram, isto não é trabalho do poeta, mas quais (coisas) poderiam acontecer, e as coisas possíveis segundo o verossímil ou o necessário. ${ }^{4}$

A mudança de Eurípides contribui, de certo modo, para ressaltar um efeito trágico ainda maior do que no mito original, pois ampliou o sacrifício de Alceste como se esta trocasse a vida pela morte, não somente em benefício do marido, mas também das crianças. A própria utilização de crianças em cena evidencia uma inovação de Eurípides, pois as personagens mirins participam integralmente do drama, o que não ocorre nas peças de Ésquilo nem de Sófocles. O primeiro nunca se utilizava desse recurso e o segundo, apesar de usar crianças en cena, sempre as deixava em silêncio sem participarem dos diálogos.

Esse é um dado importante, pois o uso das crianças nos mostra um dos recursos pelos quais o tragediógrafo trabalha em cena: a compaixão (éleos). Em Alceste, as crianças se encontram diante do cadáver da mãe, e o filho mais velho lamenta sobre o corpo sem vida a própria orfandade.

Logo no início da peça, poderíamos pensar que a situaçāo trágica de Admeto suscitaria a compaixão, pois, segundo Aristóteles, a compaixão é despertada a respeito

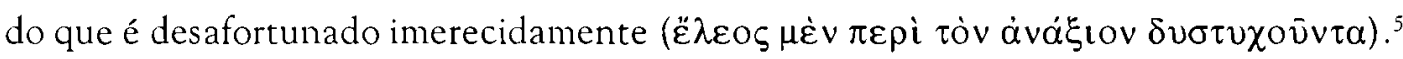
E Adneto é um homem afortunado, tem uma bela e leal esposa, riqueza e filhos.

No prólogo de Alceste, encontramos Apolo e Thânatos. ${ }^{6} \mathrm{Na}$ primeira fala de Apolo, o espectador fica sabendo o porquê de sua presença ali e que, na verdade, este deus conseguiu enganar as Moiras fazendo com que permitissem outro morto em lugar de Admeto. Ao iniciar a peça com a fala de Apolo, Eurípides dispõe de um recurso que dá credibilidade à sua forma de narrar o mito e dá também credibilidade à nobreza de Admeto, nāo só porque Apolo é um deus oracular que fala no recinto sagrado (témenos), mas também porque o próprio deus ressalta o caráter justo de Admeto:

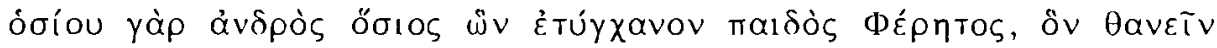

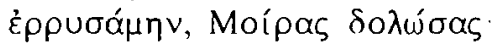

Pois sendo justo encontrei um homem justo no filho de Feres, o qual livrei da morte, enganando as Moiras.?

\footnotetext{
${ }^{3}$ Eurípedes. Alceste, v.285-9.

${ }^{4}$ Aristóteles. Poética, c.9, 1451 A, 36-8. Traduçāo minha.

${ }^{5}$ IBIDEM. C. 13, 1453A, 5.

${ }^{6}$ EURÍPEDES. Alceste, v. 1-30.

${ }^{7}$ IBIDEM. v.10-2.
} 
Aristóteles apresenta duas espécies de composição da tragédia: a composição simples, em que a metabolé, reversão da fortuna, acontece sem reconhecimento e peripécia, e a composição complexa, em que a metabolé se dá através do reconhecimento ou da peripécia, ou de ambos, que ocorrem devido à necessidade ou à verossimilhança.

Em Alceste, a reversão da fortuna tem lugar a partir da figura de Héracles, que se dirigia para a Trácia a fim de realizar o seu oitavo trabalho: ${ }^{8}$ capturar os cavalos antropófagos de Diomedes.

O diálogo de Héracles e Admeto é confuso, ou melhor, é um exercício de retórica. A inquietação causada pelo filho de Feres ao aparecer em cena com a cabeça raspada faz com que Héracles lhe faça muitas perguntas e Admeto lhe dá respostas fugidias e vagas, mesmo quando é interrogado diretamente se a morta é Alceste. Persuadindo o hóspede a ficar, ordena aos criados que levem Héracles para o interior do palácio e que o recebam com todas as honras da hospitalidade grega.

Eurípides aproveita este momento, através da fala do coro, para louvar o caráter extraordinariamente hospitaleiro de Admeto:

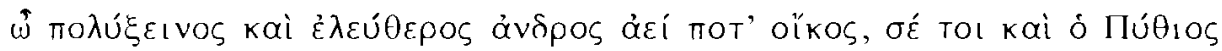

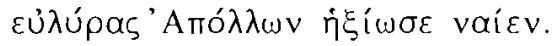

Ó casa sempre hospitaleira de um homem liberal, também Apolo Pítio, de lira melodiosa, se dignou habitar-te e se resignou a ser pastor em tua casa. ${ }^{10}$

Seria esse caráter "demasiadamente" hospitaleiro que possibilitaria enquadrar Admeto nos tipos propostos no capítulo treze da Poética? Seria natural um homem receber um hóspede para banquetear em sua casa enquanto enterra a própria esposa?

Não, não é uma atitude comum. Admeto se destaca pela hospitalidade, e talvez por isso poderia até ser definido como um epieikés ( $\dot{\varepsilon} \pi \imath \imath \kappa \dot{\zeta} \zeta$ ). No entanto, o epieikés nos é fornecido como exemplo de um homem justo que se encontra na boa fortuna e passa para a má fortuna, mas deste modo não desperta nem temor, nem compaixão, e sim a repugnância. Contudo, neste momento, a metabolé, reversão da fortuna, ainda não ocorreu; neste ponto da peça Admeto já se encontra em infortúnio.

Aristóteles descreve um tipo intermediário que se encontraria entre o epieikés e o homem perverso ( $\mu \circ \chi \theta \eta \rho o ́ \varsigma)$, um tipo que goza de grande fortuna e reputação, assim como Admeto, mas que sofre a metabolé devido a um grande erro (hamartía). Aqui seria possível enquadrar o filho de Feres se pensarmos que a simples aceitação do sacrifício da esposa constituiria sua hamartia e conseqüentemente que a sua hamartía decorre do seu intento de querer evitar a condição de mortal. Como já foi dito, na composição complexa, encontramos a peripécia ou o reconhecimento, ou ambas. Vale a pena rever a definição de peripécia:

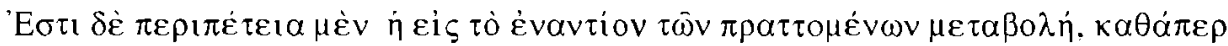

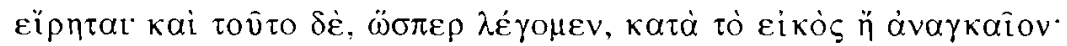

E é peripécia a mudança para o contrário das coisas agidas, como foi dito; e isto, como falamos, conforme o verossímil e o necessário."

\footnotetext{
${ }^{8}$ Graves. Los mitos griegos, p.152-5.

${ }^{9}$ Eurípedes. Alceste, v.561-7.

10 IBIDEM. v. 569-71.

1 Aristóteles. Poética, c.11, 1452A, 22-4.
} 
Se a peripécia é uma reviravolta no esperado, a ação de Héracles é peripécia, pois ele é o hóspede que chega em hora inoportuna e é definido pelo criado como um hóspede odioso, ${ }^{12}$ devido ao seu comportamento. O filho de Zeus se embriagava, coroado de mirto, e cantarolava pelo palácio. Se é verdade, como afirma Lesky, ${ }^{13}$ que este Héracles alegre e beberrão é característica da comédia dórica, então teríamos nesta cena o ponto alto do burlesco em Alceste. Mas aqui presenciamos a hýbris (desmedida) de Héracles que o persegue em muitos momentos de sua vida. ${ }^{14}$ Após ser alertado pelo criado sobre a situação de Admeto, Héracles se sente envergonhado e quer recompensar Admeto pela sua generosidade e também se redimir diante do seu comportamento inadmissível. E assim o herói se dirige ao túmulo de Alceste a fim de aguardar Tânatos para uma luta por Alceste.

Grimal $^{15}$ afirma que a intervenção de Héracles tem desenvolvimento tardio, pois, no mito primitivo, a própria Perséfone, sensibilizada com a atitude de Alceste, permite a esta voltar à vida. No capítulo nove, Aristóteles afirma não ser necessário seguir à risca os mitos tradicionais, "pois nada impede algumas coisas que aconteceram serem tais quais seria possível e verossímil acontecerem, segundo o que aquele é criador (o poeta) delas". ${ }^{16}$

Logo, a intervenção de Héracles era possível de acontecer, é verossímil em relação ao mito. Além da verossimilhança, Aristóteles nos alerta que a peripécia deve ocorrer também por força da necessidade. A escolha por Eurípides de outra versão a respeito da volta de Alceste à vida faz com que a ação de Héracles em Alceste seja necessária à ordenação dos fatos e, principalmente, ao desfecho da peça.

O reconhecimento é outra característica essencial à composição complexa. Aristóteles aponta como a forma mais bela de reconhecimento aquela que se dá simultaneamente à peripécia, ${ }^{17}$ porque suscita o temor e a compaixão. $O$ reconhecimento é definido como

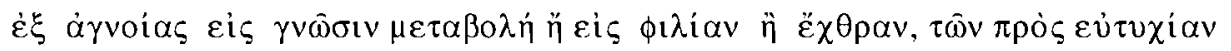

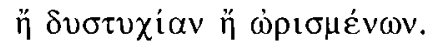

a mudança da ignorância para o conhecimento ou para a amizade ou para o ódio dos que estão definidos em relação à boa ou à má fortuna. ${ }^{18}$

No final da peça, Héracles pede a Admeto que acolha uma estrangeira. O filho de Feres fica transtornado por sua promessa de fidelidade a Alceste e o reconhecimento só ocorre depois que Héracles obriga Admeto a segurar a mão da jovem e olhar para ela. Há reconhecimento nesta cena se observarmos que a situação real de Admeto, neste

\footnotetext{
12 EURípEDES. Alceste, v.749-50, 771-2.

${ }^{13}$ LeSkY. A tragédia grega, p. 165.

${ }^{14}$ A desmedida de Héracles é comum e está presente em várias situações, como quando tinha dezoito anos e seu professor de música, Lino, resolveu castigá-lo por sua indisciplina, mas Héracles não quis deixar-se castigar e, encolerizado, acertou o professor com a lira e o matou. Diante do tribunal, é absolvido ao citar uma famosa sentença de Radamanto segundo a qual se tinha o direito de matar o adversário em caso de legítima defesa. Cf. GRIMAL. Dicionário de mitologia grega e romana, p. 206.

${ }^{15}$ Grimal. Dicionário de mitologia grega e romana, p.216-7.

${ }^{16}$ Aristóteles. Poética, c.9, 1451B, 31-3.

${ }^{17}$ IBIDEM. c. $11,1452 \mathrm{~A}, 32-3$.

${ }^{18}$ IBIDEM. c.11, 1452A, 30-2. Tradução minha.
} 
momento, é desconhecida por ele e que o filho de Feres pensa que sua situação está definida em relação à má fortuna. Encontramos apenas o reconhecimento de uma personagem, mas Aristóteles afirma que o reconhecimento em certos casos pode ser apenas de uma para a outra pessoa, nestas ocorrências em que fique claro quem seja a outra. ${ }^{19}$ Além do mais, Héracles afirma que só é permitido a Alceste ouvir a voz de Admeto e ver a luz depois de três dias, até que fosse purificada da sua consagração aos deuses subterrâneos. ${ }^{20}$

Finalmente, falta-nos refletir sobre de que modo o mito despertaria o phóbos. Sem dúvida, Alceste não é a peça que se enquadra melhor na definição aristotélica de tragédia, mas encontramos várias características que nos possibilitam pensar em Alceste como essencialmente trágica, a começar pela escolha do mito, já que, segundo Aristóteles, "as mais belas tragédias versam sobre poucas famílias... ou sobre os que fizeram ou padeceram coisas terríveis". ${ }^{21}$

Mesmo diante da reversão da má para a boa fortuna, a situação trágica de Admeto se arrasta por toda a peça e o espectador-leitor acompanha o sofrimento dele quando tem Alceste sucumbindo em seus braços, quando ocorre o agón entre Admeto e Feres, seu pai, e, principalmente, quando aquele volta do enterro e, percebendo que escapou ao destino, só consegue vislumbrar o infortúnio. ${ }^{22}$ Neste momento, Admeto alcança a compreensão de sua real situação e é possível afirmar que a catarse, a purificação de tais emoções (terror e compaixão), se concretiza.

Aristóteles afirma que o temor ocorre em relação àquele que nos é semelhante e Admeto através do seu constante sofrimento possibilita uma identificação do leitorespectador com a personagem. A situação trágica de Admeto obriga-nos a pensar no medo da morte, na imprevisibilidade da vida e na possibilidade da falta dos entes amados. O leitor-espectador pode sentir-se próximo a Admeto porque podemos presenciar sua nobreza e também sua atitude leviana diante de seu pai. Podemos pensar num homem que, como nós, não está preparado para a morte e espera que qualquer um se ofereça para morrer em seu lugar.

Alceste ocupava o quarto lugar de uma tetralogia, o que a enquadraria como um drama satírico nas representações, mas encontramos poucos traços burlescos nesta peça, e não é só Alceste que termina em boa fortuna, mas também Ifigênia em Taúride. Lesky afirma que Eurípides tinha por costume substituir a quarta peça da tetralogia por outro drama não-satírico de epílogo feliz. ${ }^{23}$ Essa questão tem sido tematizada por muitos estudiosos ao longo dos tempos e, na verdade, tornou-se uma pesada tarefa explicar como Alceste seria um drama satírico, já que possui tantos elementos próprios da tragédia.

\footnotetext{
${ }^{19}$ Aristóteles. Poética, c.11, 1452B, 4-5.

${ }^{20}$ Eurípedes. Alceste, v.1144-6.

21 ARISTóteles. Poética, c.13, 1453A, 18-21. Tradução minha.

22 Eurípedes. Alceste, v.935-61.

${ }^{23}$ LeSKY. A tragédia grega, p. 170.
} 


\section{RÉ S U MÉ}

Il y a des plusieurs controverses autour du genre tragique d'Alceste. Et le grand défi dans cette pièce est la redécouvrir dans les prémisses aristotéliques qui definent une tragédic. Euripide éveillera la compassion - éleos et la peur — phóbos — en menant le publique a la kathársis, même si pour cela soit nécessaire introduire des inovations dans la scène et des modifications dans le mythe.

\section{MOTS-CLÉS}

éleos, phóbos, kathársis

\section{REFERÊNCIAS BIBLIOGRÁFICAS}

Aristóteles. Poética. Prefácio, tradução, introdução e apêndices de Eudoro de Souza. Porto Alegre: Globo, 1966.

Aristóteles. Poétique. Introdução e tradução de J. Hardy. Paris: Les Belles Lettres, 1932.

Aristóteles. Poética. Edição trilíngüe por Valentín Garcia Yebra. Madrid: Editorial Gredos, 1974.

Dyson, M. Alcestis'children and the character of Admetus. The Journal of Hellenic Studies, London, n.123, 1988, p.13-23.

Eurípides. Alcestis. Introduçāo e comentário de A.M. Dale. London: Oxford, 1954.

EurRípldes. Alceste. Introdução, traduçāo do grego e notas de Manuel de O. Pulquério e Maria Alice N. Malça. Coimbra, 1990.

Graves, Robert. Los mitos griegos. Madrid: Alianza Editorial, 1985.

Grimal, Pierre. Dicionário de mitologia grega e romana. 3.ed. Rio de Janeiro: Bertrand Brasil, 1997.

LESKY, Albin. A tragédia grega. São Paulo: Perspectiva, 1971.

Otтo, Walter F. Los dioses de Grecia. Buenos Aires: Editoria Universitária de Buenos Aires, 1973.

Oтто, Walter F. Teofania. Buenos Aires: Editoria Universitária de Buenos Aires, 1978.

Pereira, Maria Helena da Rocha. Estudos de História da Cultura Clássica. Lisboa: Calouste Gulbenkian, 1970. 